УДК 343.211

ББК 67.408 .0

Анализ эффективности уголовной ответственности
за совершение преступлений, предусмотренных ст. 264 УК РФ

А.В. Городов

Алтайский государственный университет (Барнаул, Россия)

\title{
Analysis of Effectiveness of Criminal Responsibility for the Commission of Crimes under Art. 264 of the Criminal Code
}

\author{
A.V. Gorodov \\ The Altai State University (Barnaul, Russia)
}

На основе изучения материалов судебной практики рассмотрены некоторые вопросы эффективности уголовной ответственности за нарушение лицом, управляющим автомобилем, трамваем либо другим механическим транспортным средством, Правил дорожного движения или эксплуатации транспортных средств, повлекшее по неосторожности причинение тяжкого вреда здоровью человека (ч. 1 ст. 264 УК РФ), а также квалифицированные составы этого преступления. Автор обращает внимание на дискуссионные вопросы размеров основного и дополнительного наказания, установленных санкцией указанной статьи, с учетом применения ст. 62 УК РФ при назначении наказания; влияния назначенного наказания на исправление осужденных, а также предупреждения совершения ими новых преступлений; особенностей учета сведений о личности виновного при назначении наказания; оснований для освобождения виновного лица от уголовной ответственности в связи с примирением с потерпевшим, а также в связи с назначением судебного штрафа; затрагиваются вопросы эффективности административного наказания ввиду большого процента многократных привлечений лиц за совершение административных правонарушений в области дорожного движения.

Ключевые слова: уголовное право, состав преступления, нарушение Правил дорожного движения, безопасность дорожного движения.

\section{DOI 10.14258/izvasu(2018)6-11}

Одной из важнейших задач уголовно-правового регулирования в России является обеспечение соблюдения лицами, управляющими автомобилем, трамваем либо другим механическим транспортным средством, Правил дорожного движения (далее -
The article, on the basis of studying the materials of judicial practice, considers some issues of the effectiveness of criminal liability for violations by a person who drive a car, a tram or other mechanical vehicle, traffic rules or vehicle operation, which caused by negligence the infliction of serious harm to human health (Part 1, st. 264 of the Criminal Code), and qualified elements of this crime. The author draws attention to the debatable questions of the size of the main and supplementary punishment established by the sanction of this article, taking into account the application of Art. 62 of the Criminal Code in sentencing; the effect of the imposed punishment on the correction of convicts, and the prevention of their commission of new crimes; the peculiarities of accounting information about the identity of the perpetrator in sentencing; the grounds for exempting the guilty person from criminal responsibility in connection with reconciliation with the victim, and in connection with the appointment of a judicial fine; the issues of the effectiveness of administrative punishment are discussed, in view of the large percentage of repeated involvement of persons for committing administrative offenses in the field of road traffic.

Key words: criminal law, offense, violation of Traffic rules, road safety.

ПДД). Нарушение ПДД может привести к причинению тяжкого вреда здоровью или гибели людей.

Уголовная ответственность за нарушение ПДД и эксплуатации транспортных средств дифференцирована в ст. 264 УК РФ посредством разделения 
ее на основной и квалифицированные составы по признакам объективной стороны (последствия причиненного преступления) и субъекта уголовной ответственности (нахождение лица, совершающего преступление, в состоянии алкогольного опьянения) [1]. При этом субъективной стороной вышеуказанного преступления является неосторожная форма вины в отношении наступивших вредных последствий, что согласно ст. 15 УК РФ автоматически определяет категорию преступления по степени и характеру общественной опасности как небольшой (ч. 1 ст. 264 УК РФ) либо средней (ч. 2-6 ст. 264 УК РФ) тяжести [2, с. 548].

Для определения эффективности уголовной ответственности за совершение преступлений, предусмотренных ст. 264 УК РФ, нами были изучены размеры и виды наказаний, назначенные судами Алтайского края, на примере 50 приговоров. Согласно результатам исследования, по ч. 1 ст. 264 УК РФ наиболее часто назначаемым видом наказания является ограничение свободы, средний срок которого составляет 1 год 4 месяца, лишь в одном приговоре было назначено окончательное наказание в виде лишения свободы сроком на 1 год 7 месяцев по правилам назначения наказания по совокупности приговоров [3]. Что касается санкции квалифицируемых составов ст. 264 УК РФ, то были установлены следующие результаты: по ч. 2 ст. 264 УК РФ судами назначалось наказание только в виде лишения свободы, средний размер которого составил 2 года; по ч. 3 ст. 264 УК РФ назначалось наказание только в виде лишения свободы, средний размер которого составил 2 года 2 месяца, при этом в 33\% случаев наказание назначалось к отбыванию условно; по ч. 4 ст. 264 УК РФ назначалось наказание в виде лишения свободы, средний размер которого составил 3 года 4 месяца, при этом максимально возможный размер наказания, установленный санкцией статьи (7 лет лишения свободы), назначался лишь в одном приговоре, по правилам назначения наказания по совокупности приговоров [4]. В 71\% приговоров назначенное наказание не превышало 3 лет лишения свободы. По ч. 5 ст. 264 УК РФ судами назначалось наказание только в виде лишения свободы, средний размер которого составил 3 года 6 месяцев, из которых 12,5\% было назначено к отбыванию условно. Максимальный размер наказания, предусмотренный санкцией ч. 5 ст. 264 УК РФ, не назначался. По ч. 6 ст. 264 УК РФ средний размер безальтернативного наказания в виде лишения свободы составил 5 лет 8 месяцев.

В абсолютном большинстве исследованных приговоров имели место смягчающие наказание обстоятельства, которые учитывались судами при назначении вида и размера наказания при отсутствии отягчающих обстоятельств (рецидива); кроме того, порядка 60\% приговоров были постановлены без проведения судебного разбирательства (в особом порядке), что также влияет на размер назначенного наказания.

Таким образом, по большинству исследованных уголовных дел максимальный срок наказания, которое возможно назначить за совершение вышеуказанного преступления, фактически значительно меньше установленного санкцией ст. 264 УК РФ, с учетом применения ч. 1, 5 ст. 62 УК РФ. При этом судами с учетом индивидуализации назначения наказания максимально возможный срок наказания не назначался, за исключением одного приговора, о котором было сказано выше.

В этом ключе хотелось бы отметить следующее: нередки случаи совершения преступлений, предусмотренных ст. 264, ст. $264^{1}$ УК РФ, лицами, имевшими судимости за совершение аналогичных преступлений. Так, приговором Центрального районного суда г. Барнаула от 19 января 2018 г. [5] подсудимый, имевший судимость по ст. $264^{1}$ УК РФ, отбывавший наказание, в том числе в виде лишения права заниматься деятельностью, связанной с управлением транспортными средствами, сроком 1 год 6 месяцев, был осужден по ст. $264^{1}$ УК РФ, с учетом ч. 2 ст. 69 УК РФ, ч. 5 ст. 70 УК РФ ему окончательно назначено наказание в виде 1 года 6 месяцев лишения свободы, в соответствии со ст. 73 УК РФ основное наказание постановлено считать условным, с испытательным сроком 1 год 6 месяцев, с лишением права заниматься деятельностью, связанной с управлением транспортными средствами, сроком на 1 год 9 месяцев.

На наш взгляд, назначенное условное наказание в данном случае не способствует цели исправления осужденного и предупреждения совершения преступлений, поскольку у указанного лица ввиду неоднократности допущенных преступных нарушений ПДД выработалась определенная манера «поведения на дороге», следовательно, получив по прошествии установленного времени водительские права, он с большой вероятностью продолжит допускать нарушения ПДД. При назначении наказания необходимо учитывать грубость допущенного виновным нарушения ПДД; степень осознанности лицом нарушения им ПДД; факты привлечения виновного лица к административной либо уголовной ответственности за нарушение им ПДД, что свидетельствует об определенной сложившейся «привычке» управления механическим транспортным средством посредством нарушения ПДД.

Вместе с тем из исследованных приговоров $32 \%$ лиц, признанных виновными в совершении преступления, предусмотренного ст. 264 УК РФ разных квалифицирующих составов, ранее неоднократно привлекались к административной ответственности за совершение административных правонарушений в области дорожного движения. Следовательно, административное наказание, назначенное данным лицам, не достигло своих целей, не способствовало пре- 
дупреждению совершения новых правонарушений как самим правонарушителем, так и другими лицами. При этом факты привлечения к административной ответственности за нарушение ПДД при принятии итоговых решений по уголовным делам учитывались как характеристика личности, однако в большинстве случаев не рассматривались как препятствие, например, к прекращению дела за примирением сторон, хотя, на наш взгляд, совершение указанного преступления лицами, ранее привлекавшимися к административной ответственности за нарушение ПДД, имеет повышенную общественную опасность.

Среди видов наказаний, предусмотренных за совершение административных правонарушений в области дорожного движения, наибольшую эффективность показывает такой вид наказания, как лишение права управления транспортными средствами [6]. Нарушители ПДД в большинстве своем с гораздо большей готовностью выплатят назначенный штраф, отбудут наказание в виде административного ареста, лишь бы их не лишили права управления транспортными средствами. Что касается уголовной ответственности, максимальный размер наиболее сурового вида наказания, установленного в ч. 1 ст. 264 УК РФ, составляет до 2 лет лишения свободы. Санкция за совершение преступления, предусмотренного ч. 6 ст. 264 УК РФ, представляет собой лишение свободы на срок от 4 до 9 лет. Также в санкции ч. 2-6 ст. 264 УК РФ предусмотрено обязательное дополнительное наказание в виде лишением права занимать определенные должности или заниматься определенной деятельностью на срок до 3 лет. В ч. 1 указанной статьи данный вид наказания не является обязательным. Заслуживает внимания позиция исследователя И.В. Танаги, согласно которой для реализации принципа дифференциации наказания в ст. 264 УК в квалифицирующих составах законодателю следовало бы изменять не только срок лишения свободы как основной вид наказания, но и срок лишения права занимать определенные должности или заниматься определенной деятельностью как дополнительный вид наказания [7]. В настоящее же время за совершение разных по степени общественной опасности преступлений, предусмотренных квалифицирующими частями ст. 264 УК РФ, назначается, по сути, дополнительное наказание в одинаковом размере, что, на наш взгляд, едва ли является правильным, не отвечает современным требованиям обеспечения безопасности дорожного движения и предупреждения этого вида преступности и не способствует эффективному предупреждению преступлений и иных правонарушений, а также не способствует реальному исправлению осужденных.

Таким образом, на наш взгляд, с учетом положений ч. 2 ст. 47 УК РФ срок дополнительного наказания в виде лишения права занимать опреде- ленные должности или заниматься определенной деятельностью должен быть установлен в зависимости от характера и степени общественной опасности преступления и может соответствовать основному наказанию в виде лишения свободы.

Как отмечалось выше, согласно общей части УК РФ, категория преступления, предусмотренного ст. 264 УК РФ, определена как небольшой или средней тяжести. В связи с этим по указанному составу преступления возможно применение ст. 76 УК РФ освобождение от уголовной ответственности в связи с примирением с потерпевшим и ст. 76.2 УК РФ - освобождение от уголовной ответственности с назначением судебного штрафа. В п. 16 Постановления Пленума Верховного Суда РФ «О судебной практике по делам о преступлениях, связанных с нарушением правил дорожного движения и эксплуатации транспортных средств, а также с их неправомерным завладением без цели хищения» от 09 декабря 2008 г. № 25 (ред. от 24.05.2016) сказано, что прекращение уголовного дела о преступлении, предусмотренном ст. 264 УК РФ, за примирением сторон является правом, а не обязанностью суда. Принимая решение, следует оценить, соответствует ли оно целям и задачам защиты прав и законных интересов личности, общества и государства [8]. Так, постановлением Ленинского районного суда г. Барнаула от 13 ноября 2017 г. [9] уголовное дело по ч. 4 ст. 264 УК РФ было прекращено за примирением сторон. Согласно материалам другого дела приговор Бийского городского суда Алтайского края от 22 марта 2018 г. [10] был отменен апелляционной инстанцией Алтайского краевого суда, уголовное дело по ч. 1 ст. 264 УК РФ прекращено в связи с примирением сторон, ссылки суда первой инстанции на характер и степень общественной опасности содеянного, невозможность выяснения добровольности заявленного ходатайства потерпевшей, а также то, что подсудимый привлекался к административной ответственности, признаны судом апелляционной инстанции несостоятельными. Подобный гуманный подход судебной практики, на наш взгляд, не может достичь целей наказания и не способствует достижению задач уголовно-правового регулирования в сфере безопасности дорожного движении, таких как охрана общественной безопасности и предупреждение преступлений.

Подводя итог, можно сделать вывод, что действующее законодательство, предусматривающее уголовную ответственность за совершение преступлений, предусмотренных ст. 264 УК РФ, нуждается в совершенствовании, при этом предлагаемые изменения должны строго соответствовать в первую очередь задачам и принципам УК РФ, а санкция вышеуказанной статьи - отвечать целям наказания, установленным общей частью УК РФ, что в настоящее время выполняется не в полной мере. 


\section{Библиографический список}

1. Уголовный кодекс РФ от 13.06.1996 № 63-Ф3 (ред. от 03.10.2018) [Электронный ресурc]. — URL: http://www. consultant.ru/document/cons_doc_LAW_10699/.

2. Комментарий к Уголовному кодексу Российской Федерации / под ред. В.М. Лебедева. - 13-е изд. - М., 2013.

3. Уголовное дело № 1-78/18 // Архив Рубцовского городского суда Алтайского края.

4. Уголовное дело № 1-333/16 // Архив Индустриального районного суда г. Барнаула Алтайского края.

5. Уголовное дело № 1-40/2018 // Архив Центрального районного суда г. Барнаула Алтайского края.

6. Баканов К.С., Васюков В.Ф. Нарушение Правил дорожного движения лицом, подвергнутым административному наказанию // Уголовный процесс. — 2016. — № 6(138).
7. Танага И.В. Эффективность уголовного наказания за совершение дорожно-транспортных преступлений // Общество и право. - 2013. - № 4.

8. О судебной практике по делам о преступлениях, связанных с нарушением правил дорожного движения и эксплуатации транспортных средств, а также с их неправомерным завладением без цели хищения : Постановление Пленума Верховного Суда РФ от 09 декабря 2008 г. № 25 (ред. от 24.05.2016) [Электронный ресурc]. — URL: http:// www.consultant.ru/document/cons_doc_LAW_82656/.

9. Уголовное дело № 1-473/2017 // Архив Ленинского районного суда г. Барнаула Алтайского края.

10. Уголовное дело № 1-256/2018 // Архив Бийского городского суда Алтайского края. 